\title{
THE PRICE OF THE LOCKDOWN - THE EFFECTS OF SOCIAL DISTANCING ON THE INDIAN ECONOMY AND BUSINESS DURING THE COVID-19 PANDEMIC
}

\author{
Hasnan Baber ${ }^{1^{*}}$ and D. Tripati Rao² \\ ${ }^{1}$ Endicott College of International Studies, Woosong University, Daejeon, South Korea \\ ${ }^{2}$ Indian Institute of Management Lucknow, Lucknow, India
}

\begin{abstract}
The decision on immediate lockdown in India put economic, social and religious activities to a grinding halt. The paper examines the impact of the lockdown and social distancing policies on economic activities in India, using a multivariate econometric model for the data collected in the period from $1^{\text {st }}$ January to $31^{\text {st }}$ August 2020. While the social distancing policy is captured in terms of internal movement, domestic travel and international travel restrictions, its effect on the economic activity and the business activity is captured through stock prices, purchasing managers' index and the exchange rate. Confirmed COVID-19 cases and related deaths are also used as the independent variables. The results reveal a significant negative impact of social distancing policies on the economic activity and the business activity, the stock market and the exchange rate. Furthermore, the economic stimulus provided by the Government could not bring a positive influence on the stock market.
\end{abstract}

Keywords: lockdown, economy, finance, COVID-19, social distancing, India

JEL Classification: E65, E62

\section{INTRODUCTION}

A pandemic is a widespread outbreak of an infectious disease capable of causing immense morbidity and mortality throughout the world en masse, having yet a potential cataclysmic economic, social, and political impacts. COVID-19 is perceived as a local virus

* Correspondence to: H. Baber, Endicott College of International Studies, Woosong University, Jayang-dong, Dong-gu, Daejeon, South Korea-34606;

e-mail: h.baber@endicott.ac.kr infection emanated from China, which rapidly spread across the world and turned into a pandemic. The 1918 influenza pandemic, also known as the Spanish flu, which had resulted in an estimated 20 million death toll due to respiratory infections, is the closest parallel to the COVID-19 (Beach, Clay \& Saavedra, 2020). Besides, resulting in the short-term scarcity of labor, the spiraling costs of production, duress on public resources and social security systems, pandemics also have a long-term "hysteresis" effect in terms of a permanent loss of a potential output 
and a higher unemployment rate. Due to increased global travel and urbanization, the likelihood of such pandemics has exponentially increased over the past century. A precedent to the COVID-19 (SARS-2) outbreak was the SARS-1 that had emerged as a major international threat in 2003. The first COVID-19 was reported in Wuhan, the Hubei Province of China, on 31st December 2019 (WHO 2020), since when the disease has affected around 98.8 million lives and has resulted in 2.19 million deaths so far (WHO 2021) ${ }^{1}$. On 30th January 2020, the WHO declared a global health emergency, the sixth time in history that such an emergency was declared. On 11th March 2020, the WHO declared this virus a pandemic, based on the fact that it had been spreading all over the world, which had disrupted normal life with severe social and economic repercussions.

The "new normal" of social distancing, prohibition on mass gatherings, shutting down business outlets, travel restrictions and the reverse migration of daily wage earners from urban pockets to rural homes has made the economic situation worse (Horowit, 2020; Larry Elliot, 2020; Ozili \& Arun, 2020; Baber, 2020), while working from home has shown some significant improvement in workers' productivity (Bridgman, 2016; Etheridge, Wang \& Tang, 2020). M. M. Alsan, M. Westerhaus, M. Herce, K. Nakashima and P. E. Farmer (2011), as well as A. Sumner, C. Hoy and E. OrtizJuarez, (2020), argue that COVID-19 will increase the number of the ultra-poor, i.e. income earnings below $\$ 1.90$ a day, by 80 million, thus posing a serious challenge to the UN sustainable development goal of ending poverty by 2030, while high-income countries usually enjoy a lower mortality rate and longer life expectancies, experiencing in turn higher economic growth (Bhargava, Jamison, Lau \& Murray, 2001; Haacker, 2004). Therefore, the COVID-19 pandemic that poses hurdles to national health programs (Gopalan \& Mishra, 2020) needs to be paid attention to so as to make health and education equally accessible to the underserved and marginalized populations in India (Chaudhary, Sodani \& Das, 2020).

Countries have taken measures intended to slow down the spreading of the virus. Social distancing norms intended to reduce the harm of the infection have been considered as an effective strategy in the early stage of the spreading of the virus, especially in the absence of vaccines (Reluga, 2010). These social distancing norms include closing schools, shopping malls and workplaces, and restrictions on organizing meetings and gatherings and holding public events (Fong, Gao, Wong, Xiao, Shiu, Ryu \& Cowling, 2020). The norms are applied differently in varied settings. For instance, while formal workforce with guaranteed income will follow social distancing norms and stay at home, numerous informal workforce will have to make a Herculean choice between starvation and going out to work (McKee \& Stuckler, 2020). Lockdown was the most efficient way for countries to slow down the spreading of the virus or achieve a decrease in the transmission of the virus. The effective reproduction number, $\mathrm{Re}$, also called $\mathrm{Rt}$, is the number of the people in a community who can be infected by an individual at any specific time. Some countries announced lockdowns early in anticipation of the health crisis, whereas others have never opted for lockdown. In the beginning, strict and complete lockdown was implemented, which implied restrictions on citizens' movements outside the boundaries, which some countries successful in keeping the Rt below 1 relaxed over time.

India reported its first case on $30^{\text {th }}$ January 2020. The pace of the outbreak was not as grave as in China, or as in the US and European countries, but the pace still called for caution. The Government found itself faced with Sophie's Choice: they had a choice to either shut down the economy in order to contain the spreading of the virus and decrease the damage done and save lives at the cost of livelihoods, on the one hand, or defer lockdown in order to save the economy from distress and a looming crisis, on the other. The Government's sudden announcement of the complete lockdown on $25^{\text {th }}$ March led to a slowdown in the economic production activities of urban centers and the reverse migration of a large population from the production activity urban center to rural areas. Consequently, manufacturing came to a grinding halt in the key sectors, such as construction, real estate and info-tech, which reflected in the collapse of the industrial stocks listed in the Bombay Stock Exchange Sensitive Index (BSE Sensex) in the aftermath. Against 
these ongoing developments, the impact of social distancing policies, travel restrictions on domestic and international flights, a surge in COVID-19 deaths and confirmed infected cases on the economic activity and the business activity, the stock market and the exchange rate (the Indian Rupee price of a US Dollar) in India are analyzed in the paper.

\section{LITERATURE REVIEW}

Compared to the Global Financial Crisis (GFC) of 2008 and other crises, the economic consequences of the COVID-19 pandemic are considered as more severe. P. K. Ozili and T. Arun (2020) opine that the economic impact of this pandemic is more severe than the GFC of 2008, with an estimated global loss of jobs of 24.3 million. In the past, major public health crises, such as SARS in 2003 and influenza A (H1N1) in 2009, exerted a systemic negative influence on international trade and economy (Madhav, Oppenheim, Gallivan, Mulembakani, Rubin \& Wolfe, 2017). However, N. Fernandes (2020) disapproves of the comparison of the COVID-19 pandemic with other global crises, including the GFC of 2008, given the fact that:

- it is a severe global pandemic,

- it affects all income segments,

- interest rates are at their record low,

- simultaneous demand and supply are shocking, and

- there are international integration and interdependency.

W. Ding, R. Levine, C. Lin and W. Xie (2020) estimate that an average increase in the spreading of COVID-19 over two months has resulted in a 12 percent drop in global stock prices. K. Kanitkar (2020) estimated that, due to the COVID 19 lockdown, the Indian economy would lose about 10-31percent of the estimated GDP for the years 2020-2021. H. S. Gopalan and A. Misra (2020) warn that India may face severe economic repercussions with an increase in poverty, the broadening of socioeconomic disparities and health care challenges. However, R. Baldwin and B. Weder di Mauro (2020) suggest that India may be shielded from economic contagion as it does not depend on the global supply chain too much.

India's lockdown strategy was hastily prepared and made the vulnerable population more exposed to economic shocks, although the desired effect of flattening the curve was achieved during the first phases of the lockdown (Lancet, 2020). Through a blend of the control actions that include restriction on movement and the closure of factories and workplaces, India tried to "flatten the curve", i.e. "reduce the number of COVID-19 cases in order to prevent the clogging and collapse of the healthcare system" (Sengupta, \& Jha, 2020). While the COVID-19 pandemic may have an adverse effect on growth (Lokhandwala \& Gautam, 2020; Sardar, Nadim, Rana \& Chattopadhyay, 2020), only attributing to COVID-19 for economic distress may not be a fair assessment given the fact that the Indian economy has already been slowing down for over the last eight quarters from 8.2 percent to 4.2 percent between Q4 2017-18 to Q4 2019-20 due to the twin secular decline of the consumption and investment rates prior to COVID-19 (Dev \& Sengupta, 2020; Rao, 2021a). However, the COVID-19 pandemic shook the informal sector which had been recovering from the slowdown post demonetization and the introduction of the goods and services tax (Ray \& Subramanian, 2020). The losses predicted due to the countrywide lockdown are estimated to exceed $\$ 4.5$ billion per day (Gopalan \& Misra, 2020).

Since early June, the lockdown has gradually been relaxed. However, in high-risk zones, i.e. the "containment" areas, restrictions are still intact. Citing the hardships faced by various economic groups, the Government of India announced an economic stimulus package called "Atmanirbhar Bharat" (Self-Sufficient India), which includes the front-loading of payments, direct benefit transfers to elderly people and widows, providing employment to migrant workers, funds for construction workers and direct food distribution (Dev \& Sengupta, 2020). 


\section{DATA AND METHODOLOGY}

In this section, whether the lockdown and the social distancing policies affected economic activities or not is empirically examined. The data were collected for the period from $1^{\text {st }}$ January to $31^{\text {st }}$ August 2020. This period of seven months includes pre-pandemic economic activities, restrictions, and stock prices. The period was divided into the pre-lockdown period, the period during the lockdown, and the postunlockdown period. The lockdown and unlockdown periods were further divided into different phases, depending upon the severity of the restrictions. The highest restrictions were those in the lockdown-1 period (25 $5^{\text {th }}$ March 2020-14 ${ }^{\text {th }}$ April 2020), during which period people were not allowed to move out of their homes or place of stay. The lowest restrictions were those in the lockdown-4 period (18 ${ }^{\text {th }}$ May 2020-31 $1^{\text {st }}$ May 2020), during which period people were allowed to move and restaurants were allowed to operate kitchens for the home delivery of food items. The main objective of the study is to examine the impact of the social distancing policies on the performance of economic/business activities and the stock market in the lockdown and unlockdown phases.

The data on the stock market related to the Opening Price (OP), the Closing Price (CP), the Lowest P (LP) and Highest Price (HP) of the listed industrial stocks obtained from the BSE SENSEX ${ }^{2}$. The data of the currency values for the period from 1st January to 31st August were extracted from Yahoo finance. The estimations included the natural logarithm of each price data in order to reduce the observed skewness in the distribution of the stock price data. On the days when the stock market was closed, the values of the last working day were used for the measurement. The Purchasing Managers' Index (PMI) was also extracted for this given period. The PMI is an indicator of the prevailing direction of economic trends in the manufacturing and service sectors. It is derived from the monthly surveys of the private sector companies. The PMI can be used as a proxy for the level of general economic/business activities (Ozili \& Arun, 2020).

Three explanatory variables were used to capture the social distancing policies, namely the following: restrictions on internal movement (RIM), domestic travel restrictions (DTR), and international travel restrictions (ITR). The restriction in internal movement (RIM) was computed from the data on the following variables: the closing of schools, the closing of workplaces, cancelling public events, restrictions on public gatherings and restrictions on public transport. The economic support (ES) packages announced by the state governments and the central government were also used as the explanatory variables. Confirmed COVID-19 cases (CC) and Confirmed COVID-19 deaths (CD) were also used as the independent variables. To minimize the observed skewness in the CC and CD data distribution, the natural logarithm of the values of these variables was taken into consideration.

The data for the RIM, ITR, DTR, ES, CC, and CD variables were collected from the Oxford COVID-19 Government Response Tracker (OxCGRT) database ${ }^{3}$, which is the database that monitors the government's policy responses during the outbreak. The OxCGRT collects publicly available information on the 19 indicators of the government's responses (see Appendix A), these indicators being of the following three types: ordinal, numerical, and text. Ordinal indicators measured policies on a simple scale of severity/intensity. The most stringent government policy being in place in a country was represented by the highest ordinal value. For instance, the "closing of schools" indicator was measured by using the following options and the coding "0-no measure", "1-closing recommend", "2-closing required (only some levels or categories, e.g. only high schools, or only public schools)" and "3-closing at all levels required". So, the values pertaining to closing schools ranged from 0 to 3 . Every index is composed of a series of individual policy response indicators. For each indicator, a score was created by taking the ordinal value and adding an extra half-point if the policy was general, rather than targeted, wherever applicable. The labeling of "targeted" meant a specific geographical region or whether they were a "general" policy applicable to the entire country. Then, the rescaling of each of these variables was performed by their maximum value so as to create a score between 0 and 100 , with a missing value equal to 0 . These scores 
were then averaged in order to obtain the composite indices of all the eight containment indicators (C1-C8). The closing policies were measured on the ordinal scale. A total of four indicators (E1-E4) recorded economic policies, such as income support to citizens or the provision of foreign aid. Two indicators (E1 and E2) were measured on the ordinal scale, whereas the other two (E3 and E4) were measured on the numerical scale. The numerical scale indicators measured a specific number, typically the value in US\$. These indicators were only reported on the day they were announced. A total of five indicators (H1-H5) recorded health system policies, such as the COVID-19 testing regime or emergency investments in the healthcare. These indicators were also measured on the ordinal and numerical scales.

The data were classified into the three major indices estimated from the 19 indicators (see Appendix A). These indices were reported on a scale from 1 to100, where 1 implies "the weakest response by the government" and 100 means "the strongest response of the government" for the given indicator. Overall, the government policy response can be grouped into the four general headings, namely:

- the Overall Government Response: the overall government response indicators during the period of the pandemic, which varied depending on the situation,

- the Containment and Health Index: testing the strategy, contact tracing, emergency funds in healthcare, the awareness of the public and investment in the vaccine development,

- Economic Support: Government support to the economy through debt relief for households/ businesses, fiscal measures and income support to households/businesses (discount coupons), and

- the Stringency Index: the application of lockdown and movement strictness. It includes the closing of schools, workplaces, markets and events.

The data were simply scoring the responsiveness of the government on different fronts and their effectiveness. A higher score in an index does not mean that the country's response is better than those which generate a lower score. The countries that never applied lockdown and effectively managed the pandemic may generate a lower score because of the absence of the lockdown measures.

The period of seven months was calibrated in the following manner: the pre-lockdown period (from $1^{\text {st }}$ January 2020 to $23^{\text {rd }}$ March 2020) was attributed the value 0 , the lockdown-1 period (from $25^{\text {th }}$ March 2020 to $14^{\text {th }}$ April 2020) was attributed the value 1, the lockdown-2 period (from $15^{\text {th }}$ April 2020 to $3^{\text {rd }}$ May 2020) was attributed the value 2, the lockdown-3 period (from $4^{\text {th }}$ May 2020 to $17^{\text {th }}$ May 2020) was attributed the value 3 , the lockdown-4 period (from $18^{\text {th }}$ May 2020 to $31^{\text {st }}$ May 2020) was attributed the value 4 , the unlock-1 period (from $1^{\text {st }}$ June 2020 to $30^{\text {th }}$ June 2020) was attributed the value 5, the unlock-2 period (from $1^{\text {st }}$ July 2020 to $31^{\text {st }}$ August 2020) was attributed the value 6 . Finally, in a fashion similar to the earlier multivariate model constructions by $\mathrm{S}$. Akter (2020); P. K. Ozili and T. Arun (2020); T. Hale, A. Petherick, T. Phillips and S. Webster, (2020) and W. C. Koh, L. Naing and J. Wong (2020), a multivariate model for empirical estimation was constructed by using the ordinary least square regressions as follows:

$$
\begin{aligned}
& E C i=C+R M i+I T R i+D T R i+E S i+C C i+C D i \\
& S P i=C+R M i+I T R i+D T R i+E S i+C C i+C D i \\
& I N R i=C+R M i+I T R i+D T R i+E S i+C C i+C D i
\end{aligned}
$$

where,

$$
\begin{aligned}
& C=\text { the constant } \\
& E C=\text { the level of general economic activities } \\
& S P=\text { the log vector of the stock market variables: } \\
& \mathrm{OP} \text { (the opening price), CP (the closing price), LP } \\
& \text { (the low price) and HP (the high price) } \\
& \text { INR = the log vector of the rupee value against the } \\
& \text { dollar: INR/USD } \\
& i=\text { a weekday. }
\end{aligned}
$$




\section{EMPIRICAL RESULTS AND DISCUSSION}

In Table 1, the descriptive statistics of the observed variables are presented. The mean value 2.79 in the lockdown signifies that the lockdown was in place during the largest number the days. The mean values of the confirmed cases and the confirmed deaths are 518017 and 11351, respectively, which is alarming and among the highest in the world. The value of the rupee ranged between 70 and 76.94 , having achieved the lowest value against the dollar from the inception after independence in 1947. The ANOVA results suggested no significant difference among the pre-/lockdown/unlock phases against the dependent variables: the PMI, the rupee value and the stock market indices, as shown in Table 2. Also, no significant differences are noticed in the confirmed cases and the reported deaths during these six pre-/ lockdown/unlock phases, which fact signifies that the stock market showed no significant change during these phases, although there was a sharp bearish trend in SENSEX from $2^{\text {nd }}$ December 2019 to $25^{\text {th }}$ March 2020. However, no significant difference was found in different phases. The confirmed cases and the deaths did not show any lockdown and lock effects, either. The Pearson two-tailed correlation is given in Table 3. All the correlations are significant at the 1-percent and 5-percent significance levels, except for those between the PMI and the confirmed cases and the confirmed deaths.

The empirical results of the study are presented in Table 4. The restrictions on internal movement have a negative significant influence on the opening, closing, lowest and highest values of the stock prices. The impact of the restrictions on movement is highly negative on the economic activities. The restrictions forced people to stay back at home. Many migrant workers left for their hometowns amidst the shutdown in factories and industries. The economic output decreased, which led to a reduction in economic activities. The restrictions on movement have a strong positive impact on the rupee-dollar value. The

Table 1 Descriptive statistics

\begin{tabular}{c|ccccc}
\hline Variables & Observations & Mean & Minimum & Maximum & Std. Deviation \\
\hline Lockdown & 244 & 2.79 & 0 & 6 & 2.51 \\
PMI & 244 & 36.21 & 5.4 & 57.5 & 17.8 \\
ES & 244 & 54 & 0 & 75 & 31.78 \\
RIM & 244 & 1.72 & 0 & 2.83 & 1.06 \\
DTR & 244 & 1.37 & 0 & 2 & 0.92 \\
ITR & 244 & 2.79 & 0 & 4 & 1.47 \\
CC & 244 & 518018 & 0 & 3621245 & 895592.74 \\
CD & 244 & 11351.25 & 0 & 64469 & 17448.9 \\
Open & 244 & 35854.24 & 26499.81 & 42263 & 4255.11 \\
High & 244 & 36187.91 & 27462.87 & 42273.87 & 4071.97 \\
Low & 244 & 35436.29 & 25638.9 & 41850.29 & 4436.34 \\
Close & 244 & 35832.53 & 25981.24 & 41952.63 & 4229.04 \\
INR/USD & 244 & 74.31 & 70.8 & 76.94 & 1.82 \\
\hline
\end{tabular}


Table 2 The one-way ANOVA sample test

\begin{tabular}{l|ccc}
\hline Dependent variable & Factor & $F$ & Sig. \\
\hline PMI & Pre/Lockdown/unlock & 219.430 & .000 \\
Open & Pre/Lockdown/unlock & 76.886 & .000 \\
High & Pre/Lockdown/unlock & 98.472 & .000 \\
Low & Pre/Lockdown/unlock & 65.746 & .000 \\
Close & Pre/Lockdown/unlock & 85.599 & .000 \\
INR/USD & Pre/Lockdown/unlock & 145.082 & .000 \\
Confirmed Cases & Pre/Lockdown/unlock & 107.055 & .000 \\
Confirmed Deaths & Pre/Lockdown/unlock & 187.534 & .000 \\
\hline
\end{tabular}

Note: RIM = restriction on internal movement. ITR = international travel restrictions. DTR = domestic travel restrictions. ES = economic support. CC = confirmed COVID-19 cases. CD = confirmed deaths.

Source: Authors

Table 3 Pearson Correlation

\begin{tabular}{|c|c|c|c|c|c|c|c|c|c|c|c|c|}
\hline & PMI & ES & RIM & DTR & ITR & CC & $C D$ & Open & High & Low & Close & $\begin{array}{l}\text { INR/ } \\
\text { USD }\end{array}$ \\
\hline PMI & 1 & & & & & & & & & & & \\
\hline $\begin{array}{l}\text { Economic } \\
\text { Support }\end{array}$ & $-.682^{* *}$ & 1 & & & & & & & & & & \\
\hline $\begin{array}{l}\text { Restriction } \\
\text { on internal } \\
\text { movement }\end{array}$ & $-.645^{* *}$ & $.942^{* *}$ & 1 & & & & & & & & & \\
\hline $\begin{array}{l}\text { Domestic } \\
\text { travel } \\
\text { restrictions }\end{array}$ & $-.720^{* *}$ & $.928^{* *}$ & $.970^{* *}$ & 1 & & & & & & & & \\
\hline $\begin{array}{l}\text { International } \\
\text { travel } \\
\text { restrictions }\end{array}$ & $-.668^{* *}$ & $.908^{* *}$ & $.933^{* *}$ & $.940^{* *}$ & 1 & & & & & & & \\
\hline $\begin{array}{l}\text { Confirmed } \\
\text { Cases }\end{array}$ & .072 & $.384^{* *}$ & $.534^{* *}$ & $.397^{* *}$ & $.439^{* *}$ & 1 & & & & & & \\
\hline $\begin{array}{l}\text { Confirmed } \\
\text { Deaths }\end{array}$ & .050 & $.432^{* *}$ & $.585^{* *}$ & $.447^{* *}$ & $.476^{* *}$ & $.990^{* *}$ & 1 & & & & & \\
\hline Open & $.732^{* *}$ & $-.697^{* *}$ & $-.574^{* *}$ & $-.659^{* *}$ & $-.647^{* *}$ & $.244^{* *}$ & $.230^{* *}$ & 1 & & & & \\
\hline High & $.766^{* *}$ & $-.708^{* *}$ & $-.592^{* *}$ & $-.686^{* *}$ & $-.664^{* *}$ & $.238^{* *}$ & $.224^{* *}$ & $.992^{* *}$ & 1 & & & \\
\hline Low & $.702^{* *}$ & $-.676^{* *}$ & $-.544^{* *}$ & $-.624^{* *}$ & $-.622^{* *}$ & $.258^{* *}$ & $.247^{* *}$ & $.996^{* *}$ & $.988^{* *}$ & 1 & & \\
\hline Close & $.742^{* *}$ & $-.690^{* *}$ & $-.569^{* *}$ & $-.662^{* *}$ & $-.646^{* *}$ & $.249^{* *}$ & $.237^{* *}$ & $.988^{* *}$ & $.997^{* *}$ & $.990^{* *}$ & 1 & \\
\hline INR/USD & $-.570^{* *}$ & $.953^{* *}$ & $.955^{* *}$ & $.905^{* *}$ & $.869^{* *}$ & $.526^{* *}$ & $.577^{* *}$ & $-.566^{* *}$ & $-.576^{* *}$ & $-.545^{* *}$ & $-.558^{* *}$ & 1 \\
\hline
\end{tabular}

**. Correlation is significant at the 0.01 level (2-tailed).

*. Correlation is significant at the 0.05 level (2-tailed).

Source: Authors 
Table 4 The effect of social distancing on the stock market, the currency value, and the economic activity

\begin{tabular}{|c|c|c|c|c|c|c|}
\hline & $\begin{array}{l}\text { Opening Price } \\
\text { (OP) }\end{array}$ & $\begin{array}{l}\text { Closing Price } \\
(C P)\end{array}$ & $\begin{array}{l}\text { Lowest Price } \\
\quad(\mathrm{LP})\end{array}$ & $\begin{array}{l}\text { HighestPrice } \\
\text { (HP) }\end{array}$ & INR/USD & $\begin{array}{c}\text { Economic } \\
\text { Activity }(E C) \text { or } \\
\text { PMI }\end{array}$ \\
\hline RIM & $\begin{array}{l}-.956 * * * \\
(-6.870)\end{array}$ & $\begin{array}{c}-.754^{* * *} \\
(-5.401)\end{array}$ & $\begin{array}{c}-1.013^{* * *} \\
(-6.592)\end{array}$ & $\begin{array}{l}-.741 * * * \\
(-6.020)\end{array}$ & $\begin{array}{c}0.732^{* * *} \\
(7.586)\end{array}$ & $\begin{array}{l}-.968^{* * *} \\
(-3.845)\end{array}$ \\
\hline ITR & $\begin{array}{c}-.220 * * * \\
(-3.741)\end{array}$ & $\begin{array}{l}-.212^{* * *} \\
(-3.586)\end{array}$ & $\begin{array}{c}-.268 * * * \\
(-4.117)\end{array}$ & $\begin{array}{l}-.185 * * * \\
(-3.548)\end{array}$ & $\begin{array}{l}-.195 * * * \\
(-4.629)\end{array}$ & $\begin{array}{c}.022 \\
(.204)\end{array}$ \\
\hline DTR & $\begin{array}{l}.365^{* *} \\
(3.467)\end{array}$ & $\begin{array}{l}.157 \\
(1.490)\end{array}$ & $\begin{array}{l}.536^{* * * *} \\
(4.609)\end{array}$ & $\begin{array}{l}.081 \\
(.870)\end{array}$ & $\begin{array}{l}-.256 * * \\
(-3.386)\end{array}$ & $\begin{array}{c}-.256 \\
(-1.342)\end{array}$ \\
\hline ES & $\begin{array}{l}-.415^{* * *} \\
(-6.546)\end{array}$ & $\begin{array}{l}-.401 * * * \\
(-6.303)\end{array}$ & $\begin{array}{l}-.466^{* * *} \\
(-6.650)\end{array}$ & $\begin{array}{c}-0.378^{* * *} \\
(-6.734)\end{array}$ & $\begin{array}{c}0.643^{* * *} \\
(14.120)\end{array}$ & $\begin{array}{c}0.084 \\
(0.736)\end{array}$ \\
\hline $\mathrm{CC}$ & $\begin{array}{l}-1.965^{* * *} \\
(-12.639)\end{array}$ & $\begin{array}{r}-1.984^{* * *} \\
(-12.708)\end{array}$ & $\begin{array}{c}-2.024 * * * \\
(-11.780)\end{array}$ & $\begin{array}{l}-1.916 * * * \\
(-13.916)\end{array}$ & $\begin{array}{l}-.060 \\
(-.539)\end{array}$ & $\begin{array}{c}-1.538 * * * \\
(-5.464)\end{array}$ \\
\hline$C D$ & $\begin{array}{l}2.857^{* * *} \\
(16.969)\end{array}$ & $\begin{array}{c}2.846^{* * * *} \\
(16.840)\end{array}$ & $\begin{array}{c}2.934^{* * *} \\
(15.767)\end{array}$ & $\begin{array}{c}2.770^{* * *} \\
(18.582)\end{array}$ & $\begin{array}{c}0.138 \\
(1.140)\end{array}$ & $\begin{array}{c}2.207^{* * *} \\
(7.242)\end{array}$ \\
\hline $\mathrm{R}^{2}$ & 0.959 & 0.958 & 0.949 & 0.968 & 0.979 & 0.857 \\
\hline Adjusted $\mathrm{R}^{2}$ & 0.919 & 0.919 & 0.901 & 0.937 & 0.958 & 0.735 \\
\hline Observation & 244 & 244 & 244 & 244 & 244 & 244 \\
\hline
\end{tabular}

Note: RIM = restriction on internal movement. ITR = international travel restrictions. DTR = domestic travel restrictions. $\mathrm{ES}=$ economic support. $C \mathrm{C}=$ confirmed COVID-19 cases. $\mathrm{CD}=$ confirmed deaths. ***, ** represent statistical significance at the 1-percent and 5-percent levels. The T-statistics are reported in parenthesis.

Source: Authors

positive impact signifies the deprecation of the rupee against the dollar, which is highly influenced by the restrictions on movement. The higher the restrictions on people's movement, the lower the economic activity and the fall in the value of the stock indices. With the heightened global risk aversion due to weak growth and COVID-19 uncertainty, India witnessed one of the highest foreign portfolio outflows with the selloffs of US\$ 16 billion in the fourth quarter of the year 2020 itself. The international travel restrictions have a mild negative significant influence on the opening, closing, lowest and highest values of the stock prices, whereas international travel restrictions have a negative significant impact on the rupee-dollar value, which implies demand for the rupee increased amidst the travel restrictions and increased the currency in circulation (RBI, 2021). Furthermore, the opposite influence of the restrictions on movement and the international travel restrictions on the rupee value can be explained by the fact that the restrictions on movement were gradually eased and were almost nil by the end of August. However, the international travel restrictions are still in place, except for the air bubble agreement with 24 countries so far. Tourists and businessmen exchange their currency for the rupee before and during travel, such trips being mostly avoided during the pandemic. Surprisingly, international travel restrictions have no influence on general economic activities, which is contrary to our expectations as trade deals are preceded by business visits to and from India. The restrictions may have motivated domestic companies to produce essential items during this pandemic, such as masks, sanitizers and medicines. In fact, India witnessed a current account surplus of US\$ 19.8 billion, with a sharp contraction in the trade deficit during the first quarter of 2021 compared to the deficit of US \$15 billion in 2020, during the same quarter (RBI, 2021). 
While the domestic travel restrictions have a positive significant influence on the opening prices of the BSE SENSEX listed stocks, with an insignificant impact on the closing prices, the domestic travel restrictions have a negative impact on the rupee-dollar value. However, the domestic air travel restrictions have an insignificant influence on the general economic activities. The results obtained suggest that the economic support announced both in terms of a monetary stimulus by the RBI (the Central Bank of India) and the fiscal stimulus package by the Government of India negatively influences the opening, closing, lowest and highest values of the stock prices, which is in contrast to an earlier study by B. N. Ashraf (2020a), who studied the stock market index of 77 countries from January to April 2020 and found that economic support did not have any influence on the stock prices. Furthermore, a positive influence on the deprecation of the rupee against the dollar was also found in the study presented in this paper. Since economic support has no significant impact on economic activities, the economic stimulus could have lifted positive sentiments in the financial and foreign exchange markets only. Moreover, together with a disruption in the local supply chain, the monetary stimulus led to a rise in the inflation level and hence in the deprecation of the exchange rate. The Government of India announced a \$22.6 billion (around one percent of the GDP) economic stimulus, which includes direct cash transfers and food security measures intended for millions of the poor hit by the lockdown during the COVID-19 pandemic. G. D. Sharma, G. Talan and M. Jain (2020) stated that that economic package had not covered some important sectors, such as tourism or transportation horticulture, and found it to be wanting to induce spending in the lower-income group (Rao, 2021b).

The coefficient of the confirmed COVID-19 cases has a strong negative influence on the opening, closing, lowest and highest values of the stock prices and a negligible negative influence in the case of the rupee-dollar value, which is indicative of a surge in the confirmed cases having a negative impact on the stock prices as previously suggested by B. N. Ashraf (2020b). The rupee value also depreciated as the cases surged and the lockdown was simultaneously eased.
Expectedly, a strong negative association between the rise in the confirmed cases and the economic activities was detected. The confirmed death cases positively influence the opening, closing, lowest, and highest values of the stock prices and have an insignificant impact on the rupee-dollar value. The confirmed death numbers have a high negative influence on the economic activities. Until $25^{\text {th }}$ March, the stock prices had been trembling and there had only been 9 confirmed death cases, whereas thereafter the stock prices started recovering, and the death rates started increasing as well. The value of the adjusted $R^{2}$ is above 90 percent for the stock prices and the INR/ US\$ value, and 73 percent in the case of the economic activities, which means that much of the variation in these prices and values is explained by the social distancing policies examined in this study. The variations in the stock prices, the exchange rate and domestic economic activities can largely be explained by the restrictions imposed on internal movement, domestic and international travel, economic stimulus packages, and a surge in the number of cases.

India imposed a complete lockdown on $25^{\text {th }}$ March 2020. People were instructed to practice social distancing and stringent restrictions were imposed on people's movement. Only the essential services such as hospitals, electricity, and water supply were open. All shops, offices, schools and factories were shut down and work from home was advised throughout the country. All international flights were suspended for an indefinite period on $20^{\text {th }}$ March and domestic flight restrictions were imposed on $24^{\text {th }}$ March. The stock market had already been on a downward spiral since 28th February, given the fact that the largest parts of Asia, Europe and the US were seriously afflicted with the spreading of the virus and the infection, given the tightened financial integration, the stock markets exhibit simultaneous booms and busts across the world (Morales \& Andreosso-O'Callaghan, 2012). H. Liu, A. Manzoor, C. Wang, L. Zhang and Z. Manzoor (2020) found a cross-market association during the crisis. Most countries in Southeast Asia are commercially integrated with China (Sun \& Hou, 2019). China constitutes 16 percent of the world economy as compared to 3 percent in 2003. Therefore, any shock in the Chinese economy has deep ripple 
effects on the world economy (Fernandes, 2020). Supply shocks and pandemics spread and depress investor sentiments, thus affecting their funding judgment, eventually exerting an impact on stock prices. In the midst of COVID-19, several stocks of reputed companies plunged more than 80 percent within a few days, some stocks having witnessed the biggest one-day fall around the world (Fernandes, 2020). In a similar vein, a strong negative impact of this pandemic on the stock prices was found in comparison with the previous financial shocks due to demonetization and the implementation of the Goods and Services Tax (GST).

\section{CONCLUSION}

In the paper, the influence of the social distancing policies implemented during the lockdown and the unlockdown periods on the economic activity and the business activity, the stock market and the exchange rate in India was analyzed. A significant negative impact of the largest number of the social distancing policies on the economy, the stock prices and the exchange rate was detected. Even the financial support announced by the Government was unable to uplift investors' sentiments. The domestic and international travel restrictions have a positive impact on the economic activities, which may be so due to a sharp fall in imports. The lockdown that helped flatten the curve and provide the space-time to brace up the health infrastructure by itself has an economic price of its own. India is presently witnessing the largest daily cases in the world. The decision to unlock, however, may be justified for the two reasons: first, it was made in order to keep the economic engine running, and second, it intended give a chance to more than 400 million poor people living below the poverty line to survive. The shutting down of various shops and factories triggered the reverse migration of laborers from the urban centers of production activities to rural areas. At the present time, as many as 400 million workers in the informal economy, constituting around 90 percent of India's workforce, are exposed to the risk of falling deeper into poverty. The Indian Prime Minister announced a $\$ 270 \mathrm{bn}$ stimulus package intended to boost the battered economy after the week-long lockdown in order to curb the coronavirus pandemic. This mediation is declared to be a drive towards building an Atmanirbhar Bharat (Self-Reliant India). However, much of the initial fiscal package was in terms of the liquidity support and a credit guarantee, and the actual fiscal expenditure turned out to be below 1.5\% of the GDP (Rao 2021b). The Nobel laureate economists Abhijit Bannerjee and Esther Duflo contend that the Indian Government needed to support the poor (Biswas, 2020). M. K. Singh and Y. Neog (2020) suggested certain measures other than the fiscal measures including cash transfers to informal workers in order to enhance spending, free testing on COVID-19, an increase in the scale of the amount of direct benefit transfers, such as Jan Dhan Yojana, MGNREGA, PM-Kisan and the pension scheme and the proper functioning of "mandies" (the agricultural products market), all in order to revive India's economy. Small, open economies and emerging markets have much bigger fiscal needs to offset the costs of the COVID-19 crisis (Cakmakli, Demiralp, Kalemli Ozcan \& Yildirim, 2020). The lockdown was eventually relaxed so as to restart the economy as the choice was left to the virus and starvation. However, the imposition of the strict lockdown had battered an already slowing down economy. In the case of the largest part of the specifically targeted sectors, such as construction, tourism, trade and hotels, economic support may be required in order to sustain economic revival and prevent a permanent loss in potential output growth, too.

\section{ENDNOTES}

${ }^{1}$ https://www.worldometers.info/coronavirus/ updated on 23-Jan -2021

2 SENSEX word is a combination of Sensitive and Index. The Sensex comprises of 30 leading stocks which are drawn from sectors and are traded actively in the exchange market.

${ }^{3}$ https://www.bsg.ox.ac.uk/research/research-projects/ coronavirus-government-response-tracker 


\section{REFERENCES}

Alsan, M. M., Westerhaus, M., Herce, M., Nakashima, K., \& Farmer, P. E. (2011). Poverty, global health, and infectious disease: Lessons from Haiti and Rwanda. Infectious Disease Clinics, 25(3), 611-622. doi:10.1016/j.idc.2011.05.004

Akter, S. (2020). The impact of COVID-19 related 'stay-athome'restrictions on food prices in Europe: Findings from a preliminary analysis. Food Security, 12(11), 719-725. doi. org/10.1007/s12571-020-01082-3

Ashraf, B. N. (2020a). Economic impact of government interventions during the COVID-19 pandemic: International evidence from financial markets. Journal of behavioral and experimental finance, 27(C). doi:10.1016/j.jbef.2020.100371

Ashraf, B. N. (2020b). Stock markets' reaction to COVID-19: Cases or fatalities? Research in International Business and Finance, 54. doi:10.1016/j.ribaf.2020.101249

Baber, H. (2020). Spillover effect of COVID-19 on the Global Economy. Transnational Marketing Journal, 8(2), 177-196. doi. org/10.33182/tmj.v8i2.1067

Baldwin, R., \& Weder di Mauro, B. (2020). Economics in the Time of COVID-19. London, UK: Centre for Economic Policy Research.

Beach, B., Clay, K., \& Saavedra, M. H. (2020). The 1918 influenza pandemic and its lessons for COVID-19. Working Paper No. 27673, National Bureau of Economic Research.

Bhargava, A., Jamison, D. T., Lau, L. J., \& Murray, C. J. (2001). Modeling the effects of health on economic growth. Journal of health economics, 20(3), 423-440. doi. org/10.1142/9789812773319_0020

Biswas, S. (2020, April). Coronavirus lockdown: Nobel Oprize economist says India must do more for poor. Retrieved September 18, 2021, from https://www.bbc.com/news/ world-asiaindia-52403589

Bridgman, B. (2016). Home productivity. Journal of Economic Dynamics and control, 71(C), 60-76. doi:10.1016/j. jedc.2016.08.003

Cakmakli, C., Demiralp, S., Kalemli Ozcan, S., \& Yildirim, M. A. (2020). COVID-19 and emerging markets: An epidemiological model with international production networks and capital flows. Working Paper No. 20/133, International Monetary Fund.
Chaudhary, M., Sodani, P. R., \& Das, S. (2020). Effect of COVID-19 on economy in India: Some reflections for policy and programme. Journal of Health Management, 22(2), 169180. doi.org/10.1177/0972063420935541

Dev, S. M., \& Sengupta, R. (2020). Covid-19: Impact on the Indian economy. Mumbai Working Papers 2020-013, Indira Gandhi Institute of Development Research, Mumbai, India.

Ding, W., Levine, R., Lin, C., \& Xie, W. (2020). Corporate immunity to the COVID-19 pandemic. Working Paper 27055, National Bureau of Economic Research. doi:10.3386/w27055

Etheridge, B., Wang, Y., \& Tang, L. (2020). Worker productivity during lockdown and working from home: Evidence from self-reports. ISER Working Paper Series 2020-12, Institute for Social and Economic Research.

Fernandes, N. (2020). Economic effects of coronavirus outbreak (COVID-19) on the world economy. Working Paper No. WP-1240-E, IESE Business School.

Fong, M. W., Gao, H., Wong, J. Y., Xiao, J., Shiu, E. Y., Ryu, S., \& Cowling, B. J. (2020). Nonpharmaceutical measures for pandemic influenza in nonhealthcare settings-social distancing measures. Emerging infectious diseases, 26(5), 976984. doi:10.3201/eid2605.190995

Gopalan, H. S., \& Misra, A. (2020). COVID-19 Pandemic and Challenges for Socio-economic Issues, Healthcare and National Programs in India. Diabetes \& Metabolic Syndrome: Clinical Research \& Reviews, 14(5), 757-759. doi.org/10.1016/j. dsx.2020.05.041

Haacker, M. (2004). The impact of HIV/AIDS on government finance and public services. In M. Haacker (Ed.). The macroeconomics of HIVIAIDS (pp. 198-258). International Monetary Fund

Hale, T., Petherick, A., Phillips, T., \& Webster, S. (2020). Variation in government responses to COVID-19. Blavatnik school of government working paper, University of Oxford.

Horowit, J. (2020). The global coronavirus recession is beginning. CNN Business. Media report. Retrieved September 18, 2021, from https://edition.cnn.com/2020/03/16/ economy/global-recessioncoronavirus/index

Kanitkar, T. (2020). The COVID-19 lockdown in India: Impacts on the economy and the power sector. Global Transitions, 2, 150-156. doi.org/10.1016/j.glt.2020.07.005 
Koh, W. C., Naing, L., \& Wong, J. (2020). Estimating the impact of physical distancing measures in containing COVID-19: an empirical analysis. International Journal of Infectious Diseases, 100(9), 42-49. doi.org/10.1016/j.ijid.2020.08.026

Lancet, T. (2020). India under COVID-19 lockdown. The Lancet, 395(10233), 1315. doi:10.1016/S0140-6736(20)30938-7

Larry Elliot, L. (2020). Prepare for the coronavirus global recession. The Guardian, Media report.

Liu, H., Manzoor, A., Wang, C., Zhang, L., \& Manzoor, Z. (2020). The COVID-19 outbreak and affected countries stock markets response. International Journal of Environmental Research and Public Health, 17(8), 2800. doi.org/10.3390/ ijerph17082800

Lokhandwala, S., \& Gautam, P. (2020). Indirect impact of COVID-19 on environment: A brief study in Indian context. Environmental research, 188. doi.org/10.1016/j. envres.2020.109807

Madhav, N., Oppenheim, B., Gallivan, M., Mulembakani, P., Rubin, E., \& Wolfe, N. (2017). Pandemics: Risks, impacts, and mitigation. In D. T. Jamison, H. Gelband, S. Horton, P. Jha, R. Laxminarayan, C. N. Mock, and R. Nugent (Eds.). Disease Control Priorities: Improving Health and Reducing Poverty. Washington (DC): The World Bank.

McKee, M., \& Stuckler, D. (2020). If the world fails to protect the economy, COVID-19 will damage health not just now but also in the future. Nature Medicine, 26(5), 640-642. doi:10.1038/s41591-020-0863-y

Morales, L., \& Andreosso-O'Callaghan, B. (2012). The current global financial crisis: Do Asian stock markets show contagion or interdependence effects? Journal of Asian Economics, 23(6), 616-626. doi:10.1016/j.asieco.2012.09.002

Ozili, P. K., \& Arun, T. (2020). Spillover of COVID-19: impact on the Global Economy. MPRA Paper 99317, University Library of Munich, Germany.

Rao, D. T. (2021a). Budget 2020: Fiscal Deficit is No. 2, Growth Revival is No. 1, Centre for Advance Trade Research (CATR). Trade Promotion Council of India, January 29.

Rao, D. T. (2021b). Indian economy needs strong immunity boosters, Centre for Advance Trade Research (CATR). Trade Promotion Council of India, September 14.
Ray, D., \& Subramanian, S. (2020). India's Lockdown: An Interim Report. Working Paper 27282, National Bureau of Economic Research.

Reluga, T. C. (2010). Game theory of social distancing in response to an epidemic. PLoS Comput Biol, 6(5), 1-9. doi. org/10.1371/journal.pcbi.1000793

Reserve Bank of India (RBI). (2020). Annual Reports. August 25, 2020.

Sardar, T., Nadim, S. S., Rana, S., \& Chattopadhyay, J. (2020). Assessment of lockdown effect in some states and overall India: A predictive mathematical study on COVID-19 outbreak. Chaos, Solitons \& Fractals, 139. doi:10.1016/j. chaos. 2020.110078

Sengupta, S., \& Jha, M. K. (2020). Social policy, COVID-19 and impoverished migrants: challenges and prospects in locked down India. The International Journal of Community and Social Development, 2(2), 152-172. doi.org/10.1177/2516602620933715

Sharma, G. D., Talan, G., \& Jain, M. (2020). Policy response to the economic challenge from COVID-19 in India: A qualitative enquiry. Journal of Public Affairs, 20(4), 1-16. doi. org/10.1002/pa.2206

Singh, M. K., \& Neog, Y. (2020). Contagion effect of COVID-19 outbreak: Another recipe for disaster on Indian economy. Journal of Public Affairs, 20(4), 1-8. doi.org/10.1002/ pa.2171

Sumner, A., Hoy, C., \& Ortiz-Juarez, E. (2020). Estimates of the Impact of COVID-19 on Global Poverty. Working Paper 43/2020, UNU-WIDER. doi.org/10.35188/UNU-WIDER/

Sun, J., \& Hou, J. W. (2019). Monetary and financial cooperation between China and the One Belt One Road countries. Emerging Markets Finance and Trade, 55(11), 26092627. doi.org/10.1080/1540496X.2018.1540976

World Health Organisation (WHO). (2021). WHO Coronavirus Disease (COVID-19) Dashboard. January 29, 2021

World Health Organisation (WHO). (2020). Novel Coronavirus (2019-nCoV) SITUATION REPORT-1. Jauary 2020. 
Received on $27^{\text {th }}$ November 2020, after revision, accepted for publication on $15^{\text {th }}$ April 2021

Published online on $23^{\text {rd }}$ April 2021.

Hasnan Baber is an assistant professor at the Endicott College of International Studies, Woosong University, South Korea.

D. Tripati Rao is a professor of economics at IIM Lucknow, India. He teaches Macroeconomic Environment, Managerial Economics and International Economics for Business to MBA students. 


\begin{tabular}{|c|c|c|}
\hline \multicolumn{3}{|c|}{ Containment and closing policies } \\
\hline ID & Name & Description \\
\hline $\mathrm{C} 1$ & C1_School closing & It records closing schools and universities. \\
\hline $\mathrm{C}_{2}$ & C2_Workplace closing & It records closing workplaces. \\
\hline $\mathrm{C}_{3}$ & C3_Cancel public events & It records cancelling public events. \\
\hline $\mathrm{C}_{4}$ & C4_Restrictions on gatherings & It records limits on gatherings. \\
\hline $\mathrm{C}_{5}$ & C5_Close public transport & It records closing public transport. \\
\hline $\mathrm{C} 6$ & $\begin{array}{l}\text { C6_Stay-at-home } \\
\text { requirements }\end{array}$ & It records orders to "shelter-in-place" and otherwise confine to the home. \\
\hline C7 & $\begin{array}{l}\text { C7_Restrictions on internal } \\
\text { movement }\end{array}$ & It records restrictions on internal movement between cities/regions. \\
\hline C8 & $\begin{array}{l}\text { C8_International travel } \\
\text { controls }\end{array}$ & $\begin{array}{l}\text { It records restrictions on international travel. } \\
\text { Note: This is only recorded by the foreign traveler policy, not the citizen policy. }\end{array}$ \\
\hline \multicolumn{3}{|c|}{ Economic policies } \\
\hline E1 & $\begin{array}{l}\text { E1 Income support } \\
\text { (for households) }\end{array}$ & $\begin{array}{l}\text { It records if the Government are providing direct cash payments to the people } \\
\text { who have lost their jobs or who are unable to work. } \\
\text { Note: It only includes payments to firms if explicitly linked to the payroll/salaries }\end{array}$ \\
\hline E2 & $\begin{array}{l}\text { E2 Debt/contract relief } \\
\text { (for households) }\end{array}$ & $\begin{array}{l}\text { It records if the Government are freezing financial obligations for households } \\
\text { (e.g. stopping loan repayments, preventing services such as water supply from } \\
\text { stopping, or banning evictions) }\end{array}$ \\
\hline E3 & E3_Fiscal measures & $\begin{array}{l}\text { Announced economic stimulus spending. } \\
\text { Note: It only records the amount additional to the previously announced } \\
\text { spending. }\end{array}$ \\
\hline E4 & E4_International support & $\begin{array}{l}\text { Announced offers of Covid-19-related aid spending to other countries } \\
\text { Note: It only records the amount additional to the previously announced } \\
\text { spending. }\end{array}$ \\
\hline \multicolumn{3}{|c|}{ Health system policies } \\
\hline $\mathrm{H} 1$ & $\begin{array}{l}\text { H1_Public information } \\
\text { campaigns }\end{array}$ & It records the presence of public info-campaigns. \\
\hline $\mathrm{H}_{2}$ & H2 Testing policy & $\begin{array}{l}\text { It records the Government policy on who has access to testing. } \\
\text { Note: This is recorded by the testing policies intended for the current infection } \\
\text { (PCR tests), not testing for immunity (the antibody test). }\end{array}$ \\
\hline $\mathrm{H}_{3}$ & H3_Contact tracing & $\begin{array}{l}\text { It records the Government policy on contact tracing after a positive diagnosis. } \\
\text { Note: The policies that would identify all the people potentially exposed to } \\
\text { Covid-19 are sought. Voluntary Bluetooth apps are unlikely to achieve this. }\end{array}$ \\
\hline $\mathrm{H}_{4}$ & $\begin{array}{l}\mathrm{H}_{4} \text { Emergency investment in } \\
\text { healthcare }\end{array}$ & $\begin{array}{l}\text { It announces short-term spending on the healthcare system, e.g. hospitals, } \\
\text { masks and so on. } \\
\text { Note: It only records the amount additional to the previously announced } \\
\text { spending. }\end{array}$ \\
\hline $\mathrm{H}_{5}$ & H5_Investment in vaccines & $\begin{array}{l}\text { It announces public spending on the development of the Covid-19 vaccine. } \\
\text { Note: It only records the amount additional to the previously announced } \\
\text { spending. }\end{array}$ \\
\hline H6 & H6_Facial coverings & It is recorded by the policies on facial coverings use outside the home. \\
\hline $\mathrm{H}_{7}$ & H7_Vaccination policy & It records policies for the vaccine delivery for different groups. \\
\hline
\end{tabular}

Source: Coronavirus Government Response Tracker (https://www.bsg.ox.ac.uk/research/research-projects/ coronavirus-government-response-tracker) 


\title{
CENA „ZAKLJUČAVANJA“ - EFEKTI SOCIJALNOG DISTANCIRANJA NA PRIVREDU INDIJE I POSLOVANJE TOKOM PANDEMIJE KOVID-19
}

\author{
Hasnan Baber ${ }^{1}$ i D. Tripati Rao ${ }^{2}$ \\ ${ }^{1}$ Endicott College of International Studies, Woosong University, Daejeon, South Korea \\ ${ }^{2}$ Indian Institute of Management Lucknow, Lucknow, India
}

Odluka o hitnom „zaključavanju“ Indije imala je za posledicu postepenu potpunu obustavu privrednih, društvenih i verskih aktivnosti. U radu se ispituje uticaj politike „zaključavanja“ i socijalnog distanciranja na privredne aktivnosti u Indiji, uz primenu multivarijantnog ekonometrijskog modela za podatke prikupljene u periodu od 1. januara do 31. avgusta 2020. Dok se restriktivnost politika socijalnog distanciranja ogleda u zabrani unutrašnjeg kretanja, putovanja unutar države i međunarodnih putovanja, efekat koji te politike imaju na privredne aktivnosti i poslovanje se sagledava u svetlu cena akcija, indeksa poslovne aktivnosti i kursa valute. Potvrđeni slučajevi Kovid-19 i potvrđeni smrtni slučajevi povezani sa tom bolešću se takođe koriste kao nezavisne varijable. Dobijeni rezultati otkrivaju značajan negativan uticaj politika socijalnog distanciranja na privrednu aktivnost i poslovanje, tržište akcija i kurs valute. Pri tome, privredni podsticaj Vlade Indije nije mogao da utiče pozitivno na tržište akcija.

Ključne reči: „zaključavanje“, privreda, finansije, Kovid-19, socijalno distanciranje, Indija

JEL Classification: E65, E62 